\title{
Exploring Selected Theories Applicable to Educational Disciplines and Social Sciences Research
}

\author{
Bentry Nkhata*, Sitwe Benson Mkandawire, Kabunga Nachiyunde, Patricia Phiri-Nalube, \\ Bestern Kaani, Innocent Mutale Mulenga, Chidongo Phiri, Bernard Chileshe, Noah Kenny, \\ Patrick Sikayomya, Jonathan C Munachaka, Dennis Banda, Felesia Mulauzi, Janet Serenje- \\ Chipindi, Ferdinand Mwaka Chipindi
}

*Corresponding Author: Bentry Nkhata, Zambia

\begin{abstract}
This paper sought to advance an understanding of selected theories applicable to educational disciplines and social sciences. The authors conducted a search on academic institutional repositories for dissertations, theses and research papers across the globe. International databases such as JSTOR, Intellect Journals Collection, and Science Direct were also searched by means of such terms and parameters as theory, educational theories, social science theories and research theories. Google Scholar, Research Gate, Academia, and Scopus were included in the search. The theories were then analyzed through cross-reference with other existing literature for validation. Notes were simultaneously taken and bookended by critical review of emerging trends. The study identified several theories which were grouped in themes based on relatedness and applicability. The theories included intersectionality, Simple View of Reading, Transformational Learning, and commognition. The article concludes that there is a lot of room for theoretical mapping of educational research efforts. Specific recommendations are proposed to help enhance the potency of education-related research.
\end{abstract}

Keywords: Theory, phenomena, research theories, educational theories, and social science theories.

\section{INTRODUCTION}

There is a convergence of opinion among various writers, that research is a process of discovering new knowledge and building theory to advance a set of conceptual ideas (Nebeker etal., 2015). In the educational realm, research is widely recognized as playing a critical role in discovering knowledge, testing hypotheses and uncovering new relationships, associations or causal imperatives about various aspects of education. This includes student learning, teaching and assessment methods, teacher training, and classroom dynamics. Social science research answers several questions about human interactions and behaviour. In both education and social sciences, research has relied on the use of theories not only to help explain, predict, and understand phenomena but also to challenge and extend existing knowledge within the limits of critical bounding assumptions (Labaree, 2009). Stewart and Klein (2015) posit that all researchers should consider the theoretical basis for their studies very early in the planning stage. When a researcher understands the employability of a theory in research, they realise that their research processes would profoundly be improved in applicability, generalisability, credibility, validity, precision and reliability. Theories are generally defined as statements about how things are connected. They help researchers to recast their thinking. Glanz, Rimer, and Viswanath (2008) assert that a theory is a set of claims about interrelatedness of concepts, definitions, and propositions that explain or predict events. Bhattacherjee (2012: 14) describes a theory as "a set of systematically interrelated constructs and propositions intended to explain and predict a phenomenon or behaviour of interest, within certain boundary conditions and assumptions." Theories are, thus, applied in research and teaching to help in illuminating concepts, facts, and ideologies that are encountered in everyday life world of a researcher. Their purpose is to explain why things happen as they do around people.

Theories can be categorised into groups based on their nature, size, density, abstractness, completeness, and quality. These categories are chiefly utilitarian such as psychological, sociological, cultural, learning, innovative, systems-centred, human-centred, cognitive, and specialised theories. Each category may further be subdivided into specific theories. For instance, learning theories refer to 
all those theories that deal with learning processes, such as behaviourism, cognitivism and constructivism. Bélanger (2011:52) noted that "learning theories provide schemes of reference for better understanding of learning processes, identifying the ways and conditions under which individual adults may develop their capacity for action and expression". Similarly, sociological theories can further be split into three foundational sub-groups such as structural functionalism, social conflict and symbolic interactionism (Spencer, 1898; Giddens, 1984). This means that each theory has a specific relevance and importance of informing education decisions and practice (Richard, 2013).

\subsection{Focus of the Study}

The focus of this desk study was three-fold. The first part focused on identifying and describing selected research theories which are applicable to educational disciplines and social sciences research. The second part focused on tracing the origins and development of the selected theories and aligning them to their main proponents. The third part focused on demonstrating how the selected theories can inform and improve the quality and relevance of educational and social science research. All the three parts have been discussed concurrently.

\subsection{Theoretical Framework}

This study was guided by the documentarist theory, which has two meanings. Firstly, documentarism refers to the art or process of inventing, writing texts and recording. Secondly, the term refers to ways of analysing written documents with a view of meeting some set objectives, including the genre of the documents, articulating their components, and describing their effects and use in society (Bergman, 2009). According to Agrell (1997:1), "documentarism is an interweaving of two comprehensive topics, the one presumably dealing with ways of inventing and writing texts and the other with ways of imagining and analysing them". This study applied documentarism using the second meaning that deals with analysis of written documents with a view of extracting relevant information. In this case, existing literature that used selected theories was analysed to ascertain the context in which the theories were used.

\section{MeTHOD}

This paper surveyed theories applied in education and social sciences research by reviewing relevant literature. Exploring these theories, analysing and synthesising them was crucial for developing a better understanding on how they are applied to different disciplines. Searches for literature were conducted on university (institutional) repositories to fetch dissertations, theses and research papers across the globe. International databases such as JSTOR, Intellect Journals Collection, and Science Direct were searched by means of such terms and parameters as theory, educational theories, social science theories and research theories. These search efforts included outlets such as Google Scholar, Research Gate, Academia, and Scopus. The theories collected from the existing literature were analysed by cross referencing them for validation. Notes were simultaneously taken and bookended by critical review of emerging trends. The authors proceeded to group identified related theories with appropriate headings. Several theories were identified and closely reviewed to showcase their applicability to educational and social sciences research.

\section{Results}

Several theories related to education and social sciences were identified and contextualised. Some of these theories such as constructivism and behaviourism were applicable to almost all disciplines while others were applicable to specific disciplinary persuasions. Specialised social sciences can also use certain theories from other disciplines such as psychology and sociology as observed by the researchers of this study. This reminds us that compartmentalising the field of scholarship into various departments, faculties or schools is largely a matter of convenience for researchers and students rather than a reflection of intrinsic differences within the subject matter. When it comes to applying theories in research, almost all our students and some more established researchers fail to underpin their studies in relevant theoretical realms. It must be understood that the main objective of social science research is to investigate social phenomena by using relevant theories to generate answers or solutions to social issues. In education and social sciences, there is a dearth of literature regarding the philosophy of epistemology, on what is true or false about social phenomena and what ought to be done to give some research a focus and direction. 


\subsection{Sociological and Psychological Theories}

Sociological and psychological theories emerged as one of the key groups of theories applied in education research. The two fields are related in the sense that they converge on two areas of human behaviour and social interactions. Psychologists study how the mind influences behaviour, while sociologists study the role of society in shaping behaviour (Fiske, 2001). The specific theories embedded in these two theories include the following:

\subsubsection{Structuralism (Structuralist Theory)}

Structuralism sees society as having interrelated parts that work together for the good of society. This theory gives more importance to the structure of something than its function. It is also considered as a method of interpretation and analysis of aspects of human cognition, behaviour, culture, and experience, which focuses on relationships of contrast between elements in a conceptual system. Structuralism holds that all human activity and its products, even perception and thought itself, are constructed and not natural, and that everything has meaning because of the language system in which we operate. In the structural functionalist theory, there is a belief that, phenomena of human life are not intelligible except through their interrelations. These interactions create relations which constitute a structure that lead to abstract law formation (Blackburn, 2008). Structuralism implies elements of human culture must be understood by way of their relationship to a broader, overarching system or structure. It works to uncover the structures that underlie all the things that humans do, think, perceive, and feel. Structuralism developed in the early 1900s by prominent thinkers such as Claude Lévi-Strauss, linguist Roman Jakobson, and psychoanalyst Jacques Lacan. Researchers apply structuralism in research to help in understanding how various components of the society are related.

\subsubsection{Post-Structuralist Theory Categorized under Critical Tradition}

The post-structuralism rejects the fundamental assumptions of structuralism, including the parameter singularity of meaning and the stability of language. As Collinson (2006:182) asserts, poststructuralists emphasize the multiplicity of meaning about such things as identity: "rather than viewing the self as an objectifiable cognitive essence, poststructuralists argue that, identity processes are fundamentally ambiguous and always in a state of flux and reconstruction." Poststructuralists also assert that the concept of 'self' as a singular and coherent entity is largely fictional and mythical because an individual's identity encapsulates opposing tensions and knowledge claims (Belsey, 2002). Thus, post-structuralists seek to disrupt the conceptions of static and stable identities and social strata and instead propagates notions of identity as social processes that are in flux and, therefore, capable of being changed in progressive ways. A key sub-theory in post-structuralism is discourse. The discourse theory refers to a system of thoughts and texts composed of ideas, attitudes, courses of action, beliefs and practices that systematically construct subjects and the worlds of which they speak. McEwan defines it similarly as "the ensemble of social practices through which the world is made meaningful" (2009: 121). In poststructuralist analysis, discourse refers to the ways in which language, with its multiplicity of meaning, comes to construct the identities of people or subjects, institutions, and cultures. For example, Larner (2000: 12) contended that discourse "constitutes institutions, practices and identities in contradictory and disjunctive ways." By this, Larner means the multiple, shifting, fragmented, and constantly fluid way poststructuralists view identities. Discourse may produce types of individuals or subjectivities through "surveillance systems that render individuals calculable and confessional subjectivities that collude in their own subordination" (Collinson, 2006: 181). Being calculable implies that, in neoliberal governmentality, humans are viewed as entities that can be measured or corrected (Chipindi, 2017). These theoretical perspectives may be utilized in educational research across some myriad foci. For instance, identity research may view the self through the poststructuralist lens to allow the emergence of interpretive frames that are not restrictive (Chipindi and Vavrus, 2018). The use of these theories may help researchers increase our understanding of the tenuous and layered nature of human interactions.

\subsubsection{Theory of Intersectionality (Interpretive Tradition)}

The Intersectionality theory states that the interconnectedness or the overlap of various social identities such as race, class, sexuality, and gender can contribute to discrimination, oppression and some form of disadvantage for an individual. In other words, the oppression and discrimination 
resulting from the overlap of an individual's various social identities is the central focus of the intersectionality theory. The theory was coined in 1989 by Kimberlé Crenshaw. The theory is applicable to those researches that attempt to understand the oppression, mistreatment, disadvantages of certain groups of people in a society in comparison to another by virtual of their background, race, gender, class and sexuality. Intersectionality is a concept in feminist theory that can help social science students to explore, analyse and evaluate overlapping of various social phenomena related to class, sexuality, and gender. The use of a feminist intersectionality concept by social research students in education can contribute to the understanding of how the pedagogy and cognitive process in teaching and learning in schools discriminates and oppresses girls and boys.

\subsubsection{Labelling Theory (Interpretive Tradition)}

The labelling theory was developed by (Becker, 1963). The theory contends that people tend to conform to labels given to them by society. For instance, when one is labelled as a deviant by society, they tend to engage in deviant behaviour. A Key concept in the labelling theory is the self-fulfilling prophecy, defined by Robert Merton as " $\ldots$ in the beginning, a false definition of the situation, evoking a new behaviour, which makes the originally false conception come true," (Rist, 1968: 477). When applied to the classroom, the concept explains how the labels that teachers give to students affect their academic performance and behaviour. The labelling theory could be utilised in studies with a focus on student behaviour and performance.

\subsection{Theories of Literacy Development}

Theories of literacy development explain the development of literacy and provide instructional guidance to promote early literacy growth (Bowser, 2012). In the context of this study, theories on literacy, and particularly reading, were selected and discussed for the interest of the readers.

\subsubsection{Simple View of Reading (Interpretive Tradition)}

The simple view of reading theory assumes that, the essence of reading is to comprehend the text (Snowling and Hulme, 2005). Hoover and Gough (1990) proposed the simple view of reading (SVR), a theoretical framework to explain reading acquisition in beginning readers. The theory posits that listening, comprehension and decoding skills underpin reading comprehension. There is a multiplicative positive reciprocal relationship between the reader's oral vocabulary and decoding or word recognition in facilitating reading comprehension. Thus, reading comprehension (RC) is equal to decoding (DC) multiplied by listening comprehension (LC); [RC = DC X LC]. According to Nation (2005), learners cannot be expected to be good text comprehenders without adequate word recognition skills and similarly, reading comprehension will fail if learners lack the linguistic comprehension...put simply, both decoding and linguistic comprehension are necessary and neither skill on their own is sufficient, if successful reading comprehension is to follow.

This theory is applied in research and education to partly explain why learners exhibit significant reading difficulties in both second language and first language instruction. This is because reading instructions are many times tailored for decoding the language, a medium for which majority of the learners have little or no listening comprehension aptitude as it is only encountered in the classroom. Learner's decoding knowledge does little to improve language text comprehension. Similarly, their well-developed oral vocabulary fails to positively impact reading comprehension in pupils' familiar languages. In most African countries, since most learners get into school with good listening comprehension skills in their mother tongue, reading instructions should focus on enhancing decoding skills for comprehension to develop well.

\subsubsection{The Dual Route Theory of Reading (Critical Tradition)}

The dual route theories of reading are assumptions or hypotheses about the cognitive building of the information processing system that learners use for spellings and reading (Ziegler and Goswami, 2005). The dual route theories mean that written language processing is accomplished by two distinct but interactive procedures that are referred to as the lexical and non-lexical routes (Rapcsak, Henry, Teague, Carnahan, and Beeson, 2007). Beginning readers' ability to read is a function of the orthographic transparency - consistency in letter-sound associations of the language under consideration, and inadvertently impacts their developmental trajectories (Aro, 2006; Seymour, Aro and Erskine, 2003). According to Share (2008), the English orthography has idiosyncratic spelling- 
sound correspondences with words ranging from those exhibiting phonetically regular spellings (for example, go, hat) to more irregular constructions (for example, choir, pseudo). Joshi, Treiman, Carreker, and Moats (2008) stated that while decoding words obeying the spelling-sound correspondence rules may be easy, reading irregularly-spelled words (choir, pseudo) and discriminating between homophones (head-heard, cite-sight, sail-sale) requires additional knowledge for unconventional clusters. Therefore, to explain how beginning readers manage to decode words that conform to conventional spellings and those that do not, Coltheart (1978) suggested the dual route theory of loud word reading. This theory is premised on the assumption that proficient reading relies on two information processing pathways which are invoked based on the orthographic transparency of the word being decoded. Due to the idiosyncrasies of, say, the English orthography, skilled readers internalise orthographic representations of frequently encountered irregularly-spelled words for subsequent lexical retrieval, whereas regularly spelled words are decoded phonetically at the sub-lexical level by relying on the readers' letter-sound correspondence knowledge. Man is and Bailey (2008: 150) stated that, "The dual-route model proposes that skilled readers use the lexical procedure to pronounce familiar words, including words that violate typical spelling sound correspondence rules... the sub-lexical procedure is used to pronounce familiar and unfamiliar regular words, and to pronounce nonsense words."

Conversely, fluent reading is achieved by successfully switching between the lexical and sub-lexical routes depending on the orthographic depth of the word being read. Authorities in the field hailed the dual route theory as an influential model in explaining sight word recognition (Lukatela and Turkey, 1998) and ranked it highly as being among "the most prolific theories in modern cognitive psychology" (Share, 2008: 557). Findings from cross-language studies on reading development reveal achievement gaps seemingly induced by diversity in orthographic transparency among alphabetic writing systems (Seymour etal., 2003); with children immersed in transparent orthographies (for example, Finnish and Spanish) achieving reading ceiling in decoding within the first year of formal learning compared to English novices who have struggles until their third year of study. This theory can be applied in research to help explain why some words may be difficult to read than others for children and adults, due to differences in phoneme grapheme correspondence visa-vis sight and nonsighted words.

\subsubsection{Psycholinguistic Grain Size Theory (Critical Tradition)}

Although the dual route theory of reading has received positive reviews and used as a reliable framework in theorising word recognition, reading development, dyslexia, and spelling proficiency, it is not without its critics weaknesses. Prominent among its many weaknesses is that orthographic transparency cannot be viewed as a lexical versus sub-lexical dichotomy because of the range of sizes, complexity, and predictability of orthographic granules that writing systems present (Aro and Wimmer, 2003; Share, 2008). Therefore, Ziegler and Goswami (2005) proposed the psycholinguistic grain size theory (PGST), a theoretical framework intended to explain how novices read "straightforward and unambiguous mapping between the two domains" (p. 3) - that is the lexical versus sublexical domains. Instead of exclusively relying on the two routes, this framework postulates that orthographic units lie on the continuum of grain-sized elements stretching from small to large grain sizes [i.e., letters $(a, l, m, z)$, graphemes ( $p h, c h, p s y)$, rimes (all in ball, aw in claw), syllable ( $g r, a s p)$, to words (choir, quartet)], which pose decoding challenges (Goswami, 2003). Thus, depending on orthographic transparency, readers constantly keep switching between small and large grain sizes (Aro and Wimmer, 2003).

According to the PGST framework, to manipulate spelling-to-sound mappings successfully, beginner readers have to overcome three challenges related to a) availability of the knowledge of the connections between orthographic units and phonological units prior to reading, b) degree of consistency in orthographic units with multiple pronunciations and phonological units with multiple spellings, and c) the increase in granularity of orthographic units required to access phonological systems has corresponding incremental effect on the number of units. This is because "there are more words than there are syllables, more syllables than there are rimes, more rimes than there are graphemes, and more graphemes than there are letters" (Ziegler and Goswami, 2005: 3), each presenting varying degrees of availability, consistency, and granularity.

Varieties in grain sizes have significant implications on the developmental trajectories of reading among bilinguals (Aro and Wimmer, 2003; Seymour etal., 2003), especially for children learning in 
orthographically contrasting writing systems, such as English and any Zambian language. In Zambia, children are confronted with varying challenges of availability, consistency, and granularity when acquiring reading skills in either a local or the English language. However, the problems may be acute in the English language because availability is obscured by inconsistencies in its phonological system, the large grain sizes exponentially increases the number of units that novices must learn. On the other hand, due to the transparency of Zambian language orthographies, novices only grapple with availability challenges at the beginning of instructions, but its consistency and the small grain sizes makes the acquisition of reading skills bearable once the alphabetic principle is mastered (Kaani, 2014). In fact, the PGST framework may provide a plausible explanation for researchers in drawing discrepancies observed in reading achievement between local languages and English (Nkamba and Kanyika, 2000; Chikalanga, 1991; Serpell, 1978), and may be a panacea to the problems negatively affecting literacy programmes in most African countries if harnessed appropriately in developing remedial interventions.

\subsubsection{Translanguaging Theory (Interpretive)}

Translanguaging is a theory which support bilingual or multilingual speakers to use their languages simultaneously as part of a communication process. The scope of translanguaging is premised on the following assumptions; (a) for multilingual speakers, languages are viewed as part of their repertoire or assets that they can access and use in their communication; (b) languages are not detached and separated but form an integrated system for people to use; (c) multilingual competence emerges out of local practices where multiple languages are negotiated for communication; (d) competence doesn't consist of separate competencies for each language, but a multicompetence that functions symbiotically for the different languages in one's repertoire; and, (e) proficiency for multilinguals is focused on repertoire building using available languages known to them by developing abilities in the different functions served by different languages rather than total mastery of each and every language independently (Canagarajah, 2011:1).

The translanguaging theory was developed by Cen Williams in 1994 and popularised by scholars such as Colin Baker (Baker, 2006), Creese and Blackledge (2010); García (2009), and García and Wei (2014). Martínez (2015: 177) noted that, "the term 'translanguaging' derives from Colin Baker's translation of the Welsh term trawsieithu that originally referred to the pedagogical practice of students writing in one language and then reading in another". Using available languages in multilingual classes to facilitate learning is what (García and Wei, 2014:39) described as using languages for educational purposes that "creates a social space that goes beyond linguistic structures". The translanguaging theory is applied in educational research interchangeably with other terms such as code switching, bilingualism, multilingualism and language shift to help in understanding language use in bilingual and multilingual classes, learners and teachers' beliefs and ideologies about language teaching and learning, impact of language policy on minority groups and other related topics. The Translanguaging theory promote language in complementation and not in competition where the weaknesses of one language is supplemented by another.

\subsubsection{Emergent Literacy Theory}

The emergent literacy theory states that there are aspects of literacy behaviours, skills, ideas, knowledge, and attitudes which children informally acquire before they formally get into classroom which facilitates the acquisition of conventional reading and writing skills. Emergent readers demonstrate literacy related skills, knowledge, and attitudes which are precursors to conventional reading and writing skills (Mkandawire, 2018). Emergent literacy theorists believe that children's listening, speaking, reading, and writing skills which children experience in the home set up are all interrelated and that they are strengthened by literacy rich home environments (Kaunda, 2019). Components of a literacy rich home environment that promote literacy in children include; having books and print materials available in the home with caregiver's reading, allowing children to scribble by providing platforms. Emergent literacy theorists believe that literacy development starts in the maternity ward (birth) to when children can read and write, and in some cases, it is ongoing. The theory was developed by Marie Clay in 1967. Emergent literacy theory is applicable in research to help understand a variety of literacy behaviours associated with children such as forms of emergent literacy taken to school, teaching and learning materials for children, designing activities liked by children and learner catered teaching strategies in early grades. 


\subsubsection{Stage Models of Reading Theory}

This theory states that by knowing the level or stage where learners are in, teachers can plan better for the educational needs of the learner. Stage models theorists such as Frith (1985), Ehri (1991), and Gough, Joel and Griffith (1992), believe that children's reading is in stages of word identification and that learners increase the number of strategies used during reading as their reading skills develop. Lower staged reading strategies remain available to a reader as they incorporate more difficult reading skills in later stages. There are four stages of Word Identification: Pre-Alphabetic, Partial Alphabetic, Full Alphabetic and Consolidated Alphabetic (Morrow and Tracy, 2012).

The Pre-Alphabetic Stage (Logographic Stage) is where learners use visual cues as primary method of word identification, might memorize words by their shape or "look", use of environmental print and logos, and word Identification is not yet related to letter - sound knowledge. Class activities rely on contextual information such as colouring, print fonts and logos. Partial Alphabetic Stage, per Godwin etal. (2013), uses "phonetic cue reading" where a word may be associated with a letter it starts with followed by two or more letters. The Full Alphabetic Stage is where learners rely more on letter sound knowledge. A learner tries to process all the letters in a word and may become tied to letter-byletter reading which slows down the reading process. Class activities for Literacy here includes: Puzzles, Word Card Games, Magnetic Letters, Alphabet Books. Magazine Search, Letter Bingo and Word Sort: Beginning, Middle, and End Sound. The consolidated Alphabetic Stage is automatic knowledge of letter - sound relationships. Students read letter patterns within words and they use word family knowledge to aid the reading process. Activities for Literacy include word Wheels, Word Family Sorts, Poetry, and Flip Books (Gunning, 2010). The stage models of reading are applied in research to help understand which aspects are learned early by early grade learners followed by which skills, can also help in classroom activities associated with each stage of a learner, and the progress learners are making in class.

\subsection{Learning Theories}

Learning theories explains how learners absorb, process, and retain knowledge during learning (Illeris, 2004; Ormrod, 2012). Therefore, learning theory and learning-theory based research provide important insights into what makes learners effective and efficient learners. Sackney and Mergel (2007: 67) assert that "theories in educational organisations provide a way of seeing and analyzing teaching, leading and learning more accurately and deeply than one otherwise could." In this section, selected theories of learning have been presented and discussed.

\subsubsection{The Commognition Theory}

Commognition is a theory of learning which states that thinking is communicating and one learns to communicate by participating in a discourse. This implies that a person learning become a better participant in practices or discourses, which is different from developing more sophisticated structures in the mind (Sfard, 2008). The theory was developed by Sfard (2007) who explained that learning entails use of increasingly better concepts and skills in practice, in interaction with other people and resources rather than acquisition of increasingly better concepts. The theory can be applied in various fields of study. For instance, in mathematics, from a discursive perspective, mathematics is viewed as a set of related discourses, and learning mathematics implies developing proficiency in the discourse of mathematics. According to Sfard (2008: 161) mathematics is a multilayered recursive structure of discourse-about-discourse, and its objects, therefore, are, in themselves, discursive constructs.

Discourses carry with them objects, visual mediators, routines and narratives (Sfard, 2007). Sfard further noted that a narrative is any text, spoken or written, that is framed as a description of objects or of relations between objects or activities with or by objects and that is subject to endorsement or rejection, that is, to being labelled true or false. Sfard (2008:161) states that "some familiarity with the objects of the discourse seems a precondition for participation, but at the same time participation in the discourse is a precondition for gaining this familiarity". This implies that learning is participation. This process is complex and often results into what Sfard (2008: 161) refers to as commognitive conflict which is "the encounter between interlocutors who use the same mathematical objects or signifiers (words or written symbols) in different ways or perform the same mathematical tasks according to differing rules". This can also be explained in terms of the old and the new discourse in that when the new discourse appears, the old discourse could be persistent and this might result into 
the hybridization of a discourse which neither resembles the new or old discourse (Sfard, 2008). Thus, systematically contradictory narratives will arise.

Visual mediators are means with which participants of discourses identify the object of their talk and coordinate their communication (Sfard, 2007: 571). Examples of visual mediators include formulae, graphs, drawings and diagrams. According to Sfard, all discursive communication is visually mediated even if the mediators are not obviously present in the discourse; they are most likely being used by participants to create narratives. They are not an aid to learning but are part and parcel of the discourse. Routines are well defined repetitive patterns in the interlocuters' actions, characteristic of a given discourse (Sfard, 2007: 572). These include procedures and mathematical practices such as looking for similarities and differences, and hence generalize and justify. How and when routines are generated should be the focus (Sfard, 2008). The how of the routine is during actions, and the when as in its applicability and closure conditions. Applicability conditions signal to the participant to use the routine, and closure condition signal to the participant that the routine has been successfully performed. With this view, two learners might seem to have the same performance and yet they are using different routines set apart by applicability and closure conditions (Sfard, 2008). Researches that apply the theory of commognition use it in understanding how learning of mathematics occurs from the discursive perspective. However, the theory has been critiqued in the sense that the use of communication has departed from its linguistic form.

\subsubsection{Constructive Description and Social Activity Theory}

The theory of description and social activity can enable the understanding of legitimate texts across curriculum, assessment, textbook, and the classroom. Dowling (1998) elaborates Bernstein's (1996) notion of classification to examine mathematical textbooks. He argues that examining both form of expression (symbols, conventions and notations) which mathematical tasks take and the content (academic or everyday/non-academic) which mathematical tasks draw from is key to determining classification of mathematical texts. Sometimes Dowling uses context to mean content. He states that a non-mathematical content has a different context from mathematics. For example, the economic practice of running a café and the domestic practice of shopping. As illustrated in Figure 1, if the domain of practice is esoteric then the form of expression and the context are mathematical and classification at both levels is strong. The public domain of practice is referred to when the form of expression and the context are non-mathematical (the everyday non-academic knowledge). Hence, classification is weak. Dowling asserts that both the descriptive and expressive domains of practice draw from the esoteric and the public domains. The descriptive domain occurs when the form of expression is strongly classified, so mathematical and the context from which the text draws is nonmathematical, and, therefore, the classification is weak. The expressive domain is because of weak classification at the level of form of expression used and strong classification at the level of context.

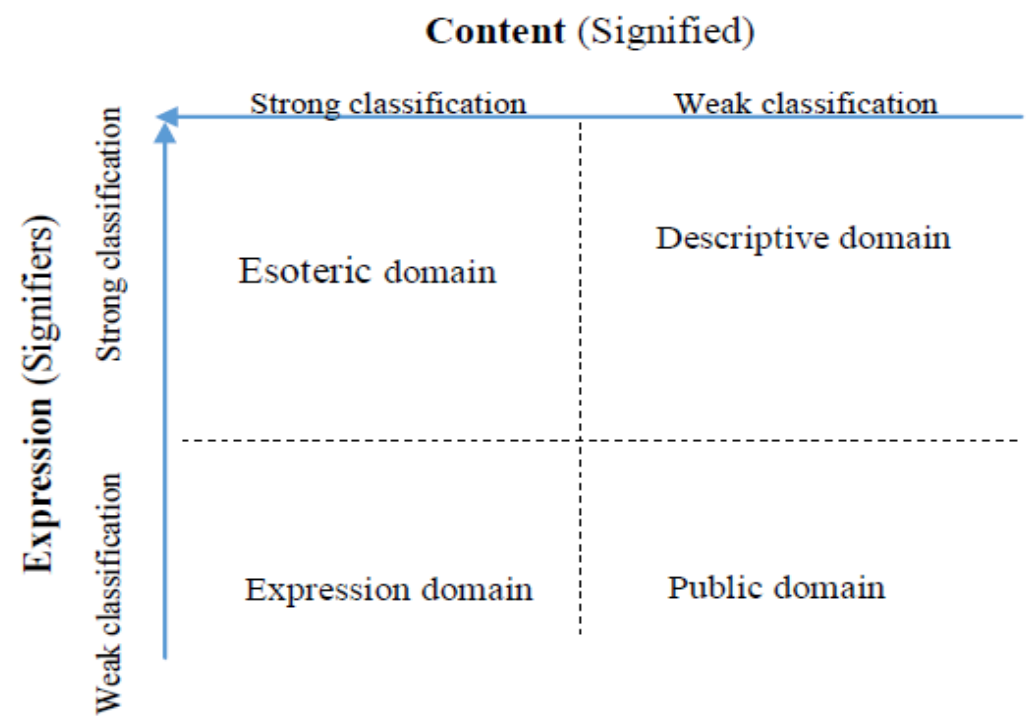

Figure1: Dowling's domains of practice.

Source: Dowling, 1998: 135 
This theory could be used to understand mathematics classroom interactions. Therefore, it is concerned with the development of higher mental functions.

\subsubsection{The Adult Learning Theory}

The adult learning theory is interwoven within the historical development of adult learning, which emerged both as a field of practice and an academic discipline in the 1920s and popularised in the 1960s (Darkenwald and Merriam, 1982; Merriam, 2001). As a field of practice, it is driven by the need to provide lifelong learning opportunities to the youth and adults (Alidou and Glanz, 2015), in different sociocultural contexts (Rogers and Street, 2012). As an academic discipline, the adult learning theory is concerned with conducting research for purposes of informing theory and practice: mainly on aspects that are related to factors and conditions that support and constrain adult learning programmes (Bélanger, 2011; Merriam, Caffarella, and Baumgartner, 2012). One fundamental model has been andragogy, complimented by the humanistic, experiential and transformation learning theories. These are pillars of the adult learning theory, because in part they emerged out of adult learning research and resonate an in-depth understanding of the adult learners and their associated learning processes.

Andragogy is attributed to the work of Malcolm Knowles who embarked on research in the 1920s to explore teaching and learning among adults. The model involves four key assumptions about adult learners, which are: (1) adult learners are self-directed learners. They often take control of their learning, by setting their own learning goals and targets, decide on the mode or method of learning and evaluate their progress (Brookfield, 1995). However, some adult learners may need help to do this as they may lack courage and confidence. (2) Adult learners possess loads of life experiences that are a resource for learning. This is crucial for both research and teaching because life experiences have been known to both facilitate and hinder learning in many adult learning situations (Knowles, 1970; Knox, 1986; Kolb, 2014). (3) Adult learners are also known to become ready to learn (formal learning) when they see the necessity and relevance to do so, and (4) they tend to be problem-centred learners, in the sense that they are motivated to learn to solve the everyday problems (Harris, 2003; Knowles, 1970).

The andragogic model, therefore, informs the pedagogy of adult learning that life experiences are a foundation for teaching and learning. In applying this model to research in education, all the four areas are crucial, although in situated cases a selection may be necessary. For example, a researcher can choose to frame the study on one or two of the assumptions depending on the focus and purpose of the study. This is to say that research that is informed by andragogy takes the theoretical and methodological orientation that is anchored on the real-life experiences of the research participants as a resource for the generation of knowledge. Therefore, the adult learning theory fundamentally is both a theoretical and methodological basis for conducting research, teaching and learning in the field of adult education. It is a knowledge base that is constituted by different sets of principles, theories and models.

\subsubsection{Behaviorism Theory}

Behaviourism is a learning theory that focuses on objectively observable behaviours and discounts any independent activities of the mind (Weegar etal., 2012). According to Anderson, Redder, and Simon (1998: 228), "one of the salient features of behaviourist movement as a psychological theory was to reject the idea of mental structures and to assert that one could understand human thinking wholly in terms of external behaviour." Behaviourism is the oldest of the learning theories. Mergel (1998) traces it back to Aristotle, although the development of the theory is attributed to John B. Watson who, in 1913, coined the term behaviourism when he wrote an article entitled 'Psychology as the behaviourist views it.' This article set out several underlying assumptions regarding methodology and behavioural analysis. Other renowned behaviourists are Ivan Pavlov, B. F. Skinner and Edward Thorndike.

Behaviourism in psychology was subsequently replaced by cognitivism. The new theory demonstrated that one could understand behaviour only by postulating mental structures and processes. However, many of the paradigms and methodologies from the behaviourist era have been carried over, often much modified and augmented, to modern cognitive psychology (Anderson et al., 1998: 228). The theory is applicable to educational research as it is often used by teachers in positive 
and negative reinforcement, shaping techniques in treatments of human disorders in psychology and special education including autism, phobias, anxiety disorders, substance abuse and antisocial behaviour (Winkler, 1971). It is also often used by teachers who use associative teaching, reward or punish student's desirable and undesirable behaviours, respectively.

\subsubsection{Social Learning Theory (Interpretive Tradition)}

Social learning theory, also characterised as social cognitive theory, stemmed out of the Neal E. Miller and John Dollard in 1941. It was expanded upon and theorised by Albert Bandura, a CanadianAmerican psychologist. The theory posits that people learn from one another, through observation, imitation, and modelling. According to Bandura (1977), people learn through observing others' behaviour, attitudes, and outcomes of those behaviours. Individuals that are observed are called models. The role models in society include parents, characters on children's TV, friends and teachers at school (McLeod, 2016). Social learning theory suggests that people are not merely products of their environment (as suggested by behaviourism) nor are they driven to behave as they do solely by internal forces (as proposed by cognitivism) (Taylor and MacKenney, 2008). The theory has often been called a bridge between behaviourist and cognitive learning theories because it encompasses attention, memory, and motivation. It is also related to Vygotsky's Social Development Theory and Lave's Situated Learning, which also emphasise the importance of social learning (David, 2019). The theory is applicable in researches that attempt to understand human learning, social behavior and other social topics. It has been used in many disciplines and sub-disciplines in education including, sociology of education, community education/learning, situated literacy learning and so forth. Again, the experts in this theory can help us to elaborate this theory brief but on point while emphasizing its application to education research.

\subsubsection{Constructivism (Critical Tradition)}

Constructivist theory states that humans construct knowledge and meaning from their experiences. The theory is used across disciplines for different purposes. Constructivism is a new rationalist movement within education which "evolved from dissatisfaction with traditional Western theories of knowledge" (Yilmaz, 2008: 161). As such, w hile the philosophical assumptions underlying both the behavioural and cognitive theories are primarily objectivistic, the philosophical assumptions for constructivism are fundamentally subjective or interpretive (Adom, Yeboah, and Ankrah, 2016). As a learning and epistemological theory, constructivism explains how people might acquire knowledge and learn (Mascolol and Fischer, 2005), proposing that knowledge is a function of how the individual creates meaning from his or her own experiences (Jonassen, 1991). The major position of constructivism is that people construct their own understanding and knowledge of the world, through experiencing things and reflecting on those experiences. When people encounter something new, they reconcile it with their previous ideas and experience, maybe changing what they believe, or maybe discarding the new information as irrelevant. In any case, humans are active creators of their own knowledge (Educational Broadcasting Corporation, 2004). In constructivism as a learning theory, the teacher's role is to help students to construct knowledge rather than to reproduce a series of facts. Constructivism covers a wide range of positions, some which are mutually contradictory or just attempt to bring the new theoretical insights of cognitive psychology into education (Anderson etal., 1998: 229). As a continuum, cognitivism has several theoretical positions, the main ones being cognitive constructivism, social constructivism, and radical constructivism.

Cognitive constructivism represents one extreme end of this constructivist continuum. Based on the work of Jean Piaget, a well-known French Swiss developmental psychologist, the theory proposes that humans cannot be given information, which they immediately understand and use; instead, humans must construct their own knowledge (Piaget, 1953, cited in Powell and Kalina (2009: 242). The pinnacle of cognitive constructivism is the assertion that each learner interprets experiences and information in the light of their extant knowledge, their stage of cognitive development, their cultural background, their personal history, and so forth.

Radical constructivism (RC) represents the opposite end of the constructivist continuum from cognitive constructivism (Doolittle, n.d.; Anderson etal., 1998). Coined by Ernst von Glasersfeld in 1974, it is the idea that all learning must be constructed (rather than perceived through the senses), and that there is no utility or meaning in instruction that is teacher or textbook driven (Riegler, 2004). 
The theory emphasises interactive learning, discovery learning, learning in complex situations, and learning in social contexts (Anderson etal., 1998).

Social constructivism lies somewhere between the transmission of knowable reality of the cognitive constructivists, and the construction of a personal and coherent reality of the radical constructivists (Doolittle, n.d.). Its epistemological emphases lead to defining principles that maintain the social nature of knowledge, and the belief that knowledge is the result of social interaction and language usage, and thus is a shared, rather than an individual experience (Prawatt and Floden, 1994).The theory also explains how social collaboration and language can impact on the development of higher mental functions of a child through the Zone of Proximal Development (ZPD) (Chaiklin, 2003), that is, how the more competent assist the young and the less competent to reach the level where they would reflect more abstractly about the nature of things (Vygotsky, 1979). McLeod, (2019) explains that some skills are too difficult for a child to master on his/her own but can be done with guidance and encouragement from a knowledgeable person. Closely related to the concept of the ZPD is that of scaffolding. The term scaffolding (sometimes known as instructional scaffolding) was introduced by David Wood, Jerome Bruner and Gail Ross, as a metaphor for the processes by which a more competent partner enables a less competent partner to carry out a task or solve a problem that the latter would be unable to complete alone (Gray and Feldman, 2004: 111). Wood etal. (1976) described scaffolding as consisting essentially of the more competent partner's controlling those elements of the task that are initially beyond the learner's capacity, thus permitting him to concentrate upon and complete only those elements that are within his range of competence. As the learner becomes increasingly skilled, the contribution of the more competent partner is reduced - the scaffold is removed, bit by bit - until the learner's performance can stand alone (Gray and Feldman, 2004).

The main proponents of constructivism are John Dewey, Jerome Seymour Bruner, Jean Piaget, and Lev Semyonovich Vygotsky. John Dewey (1933 - 1998) is often cited as the philosophical founder of constructivism. He is known for creative and collaborative learning (Reece, 2013, : 320). Jerome Seymour Bruner $(1915-2016)$ is considered the chief theorist among the cognitive constructivists and is known for discovery learning (Bada, 2015). Jean Piaget (1896-1980) is known for cognitive development theory (Ackermann, 2001) while Lev Semyonovich Vygotsky (1896-1943) is the major theorist among the social constructivists. He is well-known for his articulation of the development of higher order mental function in the zone of proximal development and social construction (Vygotsky, 1978; Gergen, 1995).

Researchers and students from different fields apply constructivism in different contexts. For instance, in science and mathematics, they frequently apply cognitive, radical and social constructivism. A review of students' dissertations and theses shows that the constructivism was narrowly linked to learner-centered strategies and that was generally considered as the most effective theory to inform teaching and learning science. One other attribute of constructivist theory as used by students concerns strategies for implementing the science and mathematics curriculum which include use of laboratory apparatus and use of learner-centered methodologies among other strategies. Constructivism was viewed as a process-oriented inquiry method of teaching of science and mathematics. In most cases, the students start by describing the general themes on social constructivism and then proceed to discussing general constructivism which touches on many aspects.

\subsection{African Indigenous Knowledge Theories}

\subsubsection{Communalism}

The coinage of the term communalism is accredited to a libertarian socialist, Murray Bookchin. Communalism usually refers to a system that integrates communal ownership of highly localised communities (Bookchin, 2006). In an African indigenous society, communalism is an important element of existence and is part of the indigenous belief of indivisibility of reality (Shroff, 2011). As Owusu-Ansah and Mji (2013: 30) put it, "the spirit of the African worldview includes wholeness, community and harmony which are deeply embedded in cultural values". For example, this theory is often applied to participatory action research in community education and development within the field adult learning (Daines, 1993). Its application is informed by the idea that a "person becomes human only during others and seeks both individual and collective harmony as the primary task in the process of becoming a true person." Communalism brings a child within the community; the child becomes a communal property as soon as he/she is born. Bringing up children is the responsibility of 
the whole community. This is the basis of Foster's (2000) assertion that "there is no such thing as an orphan in Africa". The child acquires a common spirit of working and living in common. Consequently, education is also a communal affair; learners receive instructions from everyone. It is the whole life of the community and it has no special time of a day or life when it takes place (Mushi, 2009). This is at variance with modern education which has been formalised to an extent that children cannot take anything as education if it is done outside a classroom (Maira and Kauka, 2018). We should relate this theory to a specific discipline in education. I have provided an example on how we use it in adult leaning through participatory action research.

\subsubsection{Functionalism (Positivism)}

The functionalist theory states that each aspect of a system or society depend on each other as they contribute to the overall stability and functioning of that system or society. Functionalism is the belief that a social pattern is best understood in terms of its consequences for, and functions in each society (Audu and Osuala, 2014). The theory describes society as a system of interconnected parts that work together in harmony to maintain a state of balance and social equilibrium for the whole (Mooney, Knox, and Schacht, 2007). Unlike structuralism which places more importance on the structure of a phenomenon, functionalism puts emphasis on the function of a phenomenon. When thought about as an aspect of African indigenous knowledge, functionalism is what makes education functional or pragmatic. It offers a way to transmit a society's knowledge, skills, and values to its youth which enables them to perform or do duties assigned to them. This is the crux of social philosophy and critical pedagogy in Africa. The role of education is to prepare children for their future role in the community as father or mother and relevant socio-economic activities (Mushi, 2009; Kasulwe, 2014). Every child has an opportunity to learn through apprenticeship and tutorship provided by the parents and village elders. Maira and Kauka (2018: 113) were of the view that whatever is learnt should enable the learner to adapt in the environment, not only as a matter of instinct but intelligently so and any research utilizing this theory must consider such issues seriously.

\subsubsection{Holisticism (or Holism)}

Holism is an ancient epistemological term which has its origin in the Greek word holos (meaning 'all, whole, entire'). A theory with contemporary application, holism posits that parts of a whole are in intimate interconnection, such that they cannot exist independently of the whole, or cannot be understood without reference to the whole (Hewson, 2015: 12). According to Christakis (2012), the theory suggests that unified 'wholes' have value and being which is inherently different from, and cannot be reduced to, the sum of their individual parts. Whichever system of reference, it should be viewed as wholes, not just as a collection of parts (Auyang, 1999; Oshry, 2008). The term is attributed to Jan Christiaan Smut (1870-1950), a South African philosopher, although its roots within Western philosophy go back to the German thinker George Wilhelm Friedrich Hegel (1770-1831), who insisted that 'the truth is the whole' (Encyclopedia of Science and Religion, 2003).

Regarding education, holism serves as a facet of an African indigenous knowledge system which approves an all-round person in terms of life, ranging from social features, cultural traits, economic character and political frame (Mwinzi, 2015). In other words, African indigenous education focuses on learning in its totality or holistically, that is, learners are taught to be all round or are prepared in diverse fields of life (Kanu, n.d., cited in Maira and Kauka, 2018). Specialisation only comes after the learners have acquired all the basic knowledge, skills and values required of them by the society. Based on this assumption, it can be stated that indigenous education requires learners to acquire multiple skills and master them all. Kasulwe (2014) calls this multiple learning.

Regarding research and education, holism can be applied contemporarily to any phenomenon and its determinants. The theory suggests that there is value in considering factors that influence a phenomenon together as integrated wholes, in addition to consideration of individual components (Michaelson etal., 2006). Implying that in education, children should be taught the various aspects that surrounds their lives and research should equally impinge on the same issues.

\subsubsection{Preparedness or Preparationism}

Parker (1976/1977: 259-260) explains that preparationism originally related to a process by which the penitent in church was gradually brought to realise his/her absolute need of and dependence on God's free grace for salvation. In psychology, the theory of preparedness states that organisms which learned to fear environmental threats faster had a survival and reproductive advantage (Seligman, 1971). In its 
current usage, the theory conceives that education should prepare children to become useful members of the community (Kasulwe, 2014). Based on this proposition, preparationism posits that the role of education is to equip the learner with skills appropriate to their gender in preparation for their distinctive roles (and survival) in society (Maira and Kauka, 2018). This does not only guarantee continuity in the supply of such specific services but also ensures that there is no unemployment in society. Therefore, research that is underpinned by this theory is concerned with generating knowledge on how people prepare for different situations and events in life and what it takes to prepare.

\subsubsection{Perennialism}

Perennialism is a theory that postulates that teachers should teach the things that are of everlasting relevance to all the people everywhere. The biggest proponents of perennialism in education were Robert Hutchins and Mortimer Adler. According to Hutchins (1954), "the objective of education is to prepare the young to educate themselves throughout their lives." For indigenous people, the role of perennialism then is to ensure the continuity of a cultural heritage (Kasulwe, 2014). Indigenous African societies may use perennial education as an important and necessary tool for preserving the status quo of their ethnic groups. Thus, perennial education has a conservative nature. Maira and Kauka (2018) explain that there are some content areas in learning (knowledge, values and skills) that are not bound by time or place. They were equally relevant in the past as they are relevant today and will be so in future. Content which exhibits the conception of timelessness must be taught by education. Thus, progressive ideas or questioning beliefs or culture may sometimes be severely punished, and at the extreme, one may even get ostracized and outcast from a community.

\subsubsection{Vitalism}

The difference between indigenous and modern or Western knowledge is the epistemology the two use. While western science commits to empirical testing and theory building, indigenous knowledge concerns itself with vitalism, the idea that life is not explainable solely by the laws of physics and chemistry, but also by the presence of a vital life-force (Hewson, 2015: 12). Vitalism as a school of science dates from Aristotle, but Lazzaro Spallanzani (1729-1799), an Italian physiologist, is known to have made important contributions to the development of holism. Ontologically, African indigenous people believe in the existence of a universe which consists of both the physical and the spiritual (metaphysical). They practice diverse spiritual traditions in the way they exercise their indigenous religions, beliefs and rites that relate to themselves and to all other living beings, an indication that they believe in the presence of a vital life-force. This theory helps in providing alternative explanation and understanding of life force.

\subsubsection{Indigenous Standpoint Theory}

The indigenous standpoint theory (IST) purport that, when working or researching in a community, there is need to involve and respect the ethos of the local people culturally, socially, spiritually, and morally, and that, actions should be done by indigenous people for their own benefit. Nakata (2007) who is also a proponent defined indigenous standpoint theory as a method of inquiry, a process for making more intelligible, "the corpus of objectified knowledge about us" as it emerges and organizes understanding of our lived realities. "Indigenous standpoint theory explores actualities of the everyday...from within that lived experience rather than deploying predetermined concepts and categories for explaining experiences" (Kwaymullina, 2017:15). In IST, it is expected that the ontology and epistemology of the work or research must reflect the ethos of the local people who should benefit from such indigenous knowledge as it is their resource and therefore, no person should claim ownership. The theory can be used in research and education to conscientise local people on issues affecting them.

\section{CONCLUSION}

The article has presented and discussed twenty-two theories covering various fields guiding students and researchers on how they can apply these theories in research and in education. The choice of which theory to use in research is determined by the nature of the study the focus being addressed. A wise selection of a theory may guide a researcher in a far more reaching way by making the processes easy to understand. It is recommended that researchers chose theories carefully and let it be reflected in various parts of the research project. If the theory chosen fails to do so, it could be that it is not appropriate for the study and therefore, re-thinking may be required. 


\section{REFERENCES}

[1] Ackermann, E. (2001). Piaget's constructivism, Papert's constructionism: What's the difference? In: Constructivism: Uses and Perspectives in Education, 1(2), 85-94, Geneva, and Research Centre in Education.

[2] Adom, D., Yeboah, A. \& Ankrah, K.A. (2016). Constructivism philosophical paradigm: Implication for research, teaching and learning. Global Journal of Arts Humanities and Social Sciences, 4, (10), 1-9.

[3] Agrell, B. (1997). Documentarism and theory of literature. Available at: https://www.researchgate. net/publication/227426514_Documentarism_and_Theory_f_Literature[Retrieved $27^{\text {th }}$ June, 2019].

[4] Alidou, H., \& Glanz, C. (Eds.). (2015). Action research to improve youth and adult literacy: Empowering learners in a multilingual world. Abuja: UNESCO Institute for Lifelong Learning (UIL).

[5] Anderson, J.R., Reder, L.M., \& Simon, H.A. (1998). Radical constructivism and cognitive psychology. Brookings Papers on Education Policy.

[6] Aro, M. (2006). Learning to read: The effect of orthography. In R. M. Joshi \& P. G. Aaron (Eds.), Handbook of orthography and literacy (pp. 531-550). Mahwah, NJ: Erlbaum.

[7] Aro, M., \& Wimmer, H. (2003). Learning to read: English in comparison to six more regular orthographies. Applied Psycholinguistics, 24, 621-635. Doi: http://dx.doi.org/10.1017/S014271640300 0316.

[8] Bada, S. O. (2015). Constructivism learning theory: A paradigm for teaching and learning. Journal of Research \& Method in Education, 5(6), 66-70.

[9] Baker, C. (2006). Foundations of bilingual education and bilingualism (4 ${ }^{\text {th }}$ ed.). Clevedon; Buffalo: Multilingual Matters.

[10] Bélanger, P. (2011). Learning theories: Discussion. In Theories in Adult Learning and Education (pp. 4952). Opladen; Farmington Hills: Verlag Barbara Budrich. Available at: http://www.jstor.org/stable/ j.ctvbkjx77.8 [Retrieved on $17^{\text {th }}$ August, 2019].

[11] Bergman, T. (2009). Documentary film theories. In W. Stephen, S.W. Littlejohn \& K.A. Foss, (Eds.) Encyclopedia of Communication Theory. SAGE Publishing. http://dx.doi.org/10.4135/97814129593 84.n118.

[12] Bhattacherjee, A. (2012). Social science research: Principles, methods, and practices. Textbooks Collection. 3. Available at: http://scholarcommons.usf.edu/oa_textbooks/3 [Retrieved on $17^{\text {th }}$ August, 2019].

[13] Blackburn, S. (2008). Oxford dictionary of philosophy, ( $2^{\text {nd }}$ ed. Revised). Oxford: Oxford University Press.

[14] Bookchin, M. (2006). What is communalism? The democratic dimension of anarchism. dwardmac. pitzer.edu. [Retrieved $18^{\text {th }}$ August, 2019].

[15] Bowser, K. (2012). Theories of literacy development. Available at: https://prezi.com/a4yxj-rcptjs/theoriesof-literacy-development/ [Retrieved $18^{\text {th }}$ August, 2019].

[16] Brookfield, S. (1995). Adult learning: An overview. International Encyclopedia of Education, 10, 375-380.

[17] Bruner, J. S. (1961). The act of discovery. Harvard Educational Review.

[18] Caruth, G. (2014). Learning how to learn: A six point model for increasing student engagement. Participatory Educational Research (PER), 1(2), 1-12.

[19] Chaiklin, S. (2003: 1). The zone of proximal development in Vygotsky's analysis of learning and instruction. In Kozulin, A., Gindis, B., Ageyev, V., Miller, S. Vygotsky's educational theory and practice in cultural context. Cambridge: Cambridge University Press.

[20] Chipindi, F.M. (2017). Neoliberal governmentality, responsibilization and deepening academic tribalism in the Zambian academy: a commentary. The International Journal of Multi-Disciplinary Research. ISSN: $3471-7102$

[21] Chipindi, F.M. \& Vavrus, F. (2018). The ontology of mention: Contexts, contests and constructs of academic identity among early-career academics at the University of Zambia. Forum for International Research in Education 4 (3), 135-150. https://doi.org/10.32865/fire2018437

[22] Christakis, N.A. (2012). Holism. In: Brockman J., (Ed.). This will make you smarter: new scientific concepts to improve your thinking. Harper; New York: 2012. pp. 81-83.

[23] Chikalanga, I. W. (1991). Inferencing in the reading process: A cross cultural study, (Unpublished $\mathrm{PhD}$ thesis). University of Reading, Reading, UK.

[24] Clay, M. (1967). Reading: The patterning of complex behaviour. Auckland, New Zealand: Heinemann Educational.

[25] Coltheart, M. (1978). Lexical access in simple reading tasks. In G. Underwood (Ed.), Strategies of Information Processing (pp. 151-216). New York, NY: Academic Press. 
[26] Daines, J. (1993). Adult learning, adult teaching. England: Nottingham University.

[27] Darkenwald, G. G., \& Merriam, B. S. (1982). Adult education: Foundations of practice. New York: Harper Collins Publishers.

[28] David, L. (2019). Social Learning Theory (Bandura), in Learning Theories. Available at: https://www. learning-theories.com/social-learning-theory-bandura.html. [Retrieved $18^{\text {th }}$ August, 2019].

[29] Doolittle, E. P. (n.d). Constructivism and online education. Available at: http://www.trainingshare. com/resources/doo2.htm [Retrieved on $18^{\text {th }}$ August, 2019].

[30] Dowling, P. (1998). The sociology of mathematics education: Mathematical myths/pedagogic traits. Studies in Mathematics Education Series 7, London: The Falmer Press.

[31] Encyclopedia of Science and Religion (2003). Holism. Available at: https://www.encyclopedia.com/ medicine/diseases-and-conditions/pathology/holism

[32] Fiske, S.T. (2001). Social psychology, Theories of. International Encyclopedia of the Social \&Behavioural Sciences, 14413-14421. https://doi.org/10.1016/B0-08-043076-7/01648- X.

[33] Foster, G. (2000). The capacity of the extended family safety net for orphans in Africa. Psychology, Health and Medicine 5 (1), 55-62.

[34] García, O. \& Wei, L. (2014). Translanguaging: Language, bilingualism and education. New York: Palgrave Macmillan, pp. 165.

[35] Gergen, K. J. (1995). Social construction and the educational process. In L. P. Steffe \& J. Gale, Constructivism in education (pp. 17-39). Hillsdale, NJ: Erlbaum.

[36] Giddens, A. (1984). The constitution of society: outline of the theory of structuration. Berkeley. ISBN 9780520052925 . OCLC 11029282.

[37] Glanz, K., Rimer, B.K., \& Viswanath, K. (2008). Health behaviour and health education: Theory, research, and practice ( $\left.4^{\text {th }} \mathrm{ed}\right)$. San Francisco: Jossey-Bass.

[38] Goswami, U. (2003). Why theories about developmental dyslexia require developmental designs. Trends in Cognitive Sciences, 7, 534-540.

[39] Goswami, U. (2005).Synthetic phonics and learning to read: A cross-language perspective. Educational Psychology in Practice, 21, 273-282. Doi: 10.1080/02667360500344823.

[40] Gray, P. \& Feldman, J. (2004). Playing in the zone of proximal development: qualities of self-directed age mixing between adolescents and young children at a democratic school. American Journal of Education, 110 (2), 108-146. The University of Chicago Press.

[41] Gunning, T. G. (2010). Creating literacy instruction for all children. $4^{\text {th }}$ Ed. Boston: Allyn and Beacon.

[42] Harris, S. (2003). An andragogical model: Learning through life experiences. Kappa Delta Pi Record, 40(1), 38-41.

[43] Hewson, M.G. (2015). Embracing indigenous knowledge in science and medical teaching, Springer.

[44] Hoover, W. \& Gough, P. (1990). The simple view of reading. Reading and Writing: An Interdisciplinary Journal, 2, 127-160.

[45] Hutchins, R. M. (1954). Great Books: The foundation of a liberal education. New York, NY: Simon \& Schuster.

[46] Illeris, K. (2004). The three dimensions of learning. Malabar, Fla: Krieger Pub. Co. ISBN 9781575242583.

[47] Jonassen, D. H. (1991b), Objectivism vs constructivism: Do we need a new philosophical paradigm. Educational Technology Research and Development, 39(3), 5-14.

[48] Joshi, M., Treiman, R., Carreker, S., \& Moats, L. (2008/2009). How words cast their spell: Spelling is an integral part of learning the language not a matter of memorization. American Educator, 32, 6 - 43.

[49] Kaani, B. (2014). The influence of orthographic opacity on reading development among Nyanja-English Bilinguals in Zambia: A cross-linguistic study. (Unpublished PhD Dissertation). Texas A\&M University, College Stattion, TX, USA.Lyon, G. (1998, March). Why reading is not a natural process. Educational Leadership, 55(6), 14-18.

[50] Kaunda, R. L. (2019). Literacy Goes to School: Emergent Literacy Experiences and Skills that Children Take to School. Multidisciplinary Journal of Language and Social Sciences Education, Volume 2, No.1, pp $251-287$

[51] Knowles, M. S. (1970). The modern practice of adult education, 41,New York: New York Association Press.

[52] Knox, A. B. (1986). Helping adults learn: Jossey-Bass San Francisco.

[53] Kolb, D. A. (2014). Experiential learning: Experience as the source of learning and development (2 ${ }^{\text {nd }}$ ed.). New Jersey: Pearson Education.

[54] Kwaymullina, A. (2017). Indigenous standpoint, indigenous stories, indigenous futures: Narrative from an Indigenous standpoint in the twenty first century and beyond. $\mathrm{PhD}$ Thesis. University of Western Australia 
[55] Lukatela, G. \& Turvey, M. T. (1998). Reading in two alphabets. American Psychologist, 53, $1057-1072$.

[56] Martínez, D. (2015). Social and behavioural theories. Hispania, 98(1), 177-178. Available from: https:// obssr.od.nih.gov/wp-content/uploads/2016/05/Social-and-Behavioral-Theories.pdf $\left[\right.$ Retrieved on $17^{\text {th }}$ August, 2019].

[57] Mascolo, M. F., \& Fischer, K. W. (2005). Constructivist theories. In B, Hopkins, R. G

[58] McLeod, S. A. (2016, Feb 05). Bandura - social learning theory. Available at: https://www.simply psychology.org/bandura.html [Retrieved 18th August, 2019].

[59] McLeod, S. A. (2019). What is the zone of proximal development? Available at: https://www.simply psychology.org/Zone-of-Proximal-Development.html [Retrieved 29th August, 2019].

[60] Mkandawire, S. B. (2018). Literacy versus Language: Exploring their Similarities and Differences. Journal of Lexicography and Terminology, 2 (1), 37-55.

[61] Mergel, B. (1998). Instructional design and learning theory. In Educational communications and technology. University of Saskatchewan.

[62] Merriam, S. B. (2001). Andragogy and self-directed learning: Pillars of adult learning theory. San Francisco: John Wiley \& Sons.

[63] Merriam, S. B. (2004). The role of cognitive development in Mezirow's transformational learning theory. Adult Education Quarterly, 55(1), 60-68.

[64] Merriam, S. B., Caffarella, R. S.,\& Baumgartner, L. M. (2012). Learning in adulthood: A comprehensive guide. San Francisco: John Wiley \& Sons.

[65] Michaelson, V., Pickett, W., King, N. \& Davison, C. (2006). Testing the theory of holism: A study of family systems and adolescent health. Preventive Medicine Reports, 4, 313-319. Doi: 10.1016/j.pmedr. 2016.07.002

[66] Morrow, L. M., \& Tracy, D. H. (2012). Lenses on reading: An introduction to theories and models $\left(2^{\text {nd }}\right.$ ed.), New York: The Guilford Press.

[67] Mushi, P.A. K. (2009). History of education in Tanzania. Dar-es-Salaam: Dar-es-Salaam University Press.

[68] Nakata, M. (2007). Disciplining the Savages, Savaging the Discipline. Aboriginal Studies Press

[69] Nation, K. (2005) Children's reading comprehension difficulties, in: M. J. Snowling \& C. Hulme (Eds). The science of reading, Oxford: Blackwell Publishing.

[70] Nebeker, C., Simon, G., Kalichman, M., Talavera, A., Booen, E., \& Lopez-Arenas, A. (2015). Building research integrity and capacity (BRIC): An Interactive Guide for Promotores/Community Health Workers. San Diego, CA: BRIC Academy.

[71] Nkamba, M. \& Kanyika, J. (1998). The quality of education: Some policy suggestions based on a survey of schools. SACMEQ Policy Research No. 5: Zambia. Paris, France: IIEP.

[72] Ormrod, J. (2012). Human learning (6 ${ }^{\text {th }}$ ed.). Boston: Pearson. ISBN 9780132595186.

[73] Owusu-Ansah, F.E. \& GubelaMji, G. (2013). African indigenous knowledge and research, African Journal of Disability, 2(1): 30. Doi: 10.4102/ajod.v2i1.30.

[74] Parker, D. (1976). Edward Taylor's preparationism: a new perspective on the Taylor-Stoddard controversy. Early American Literature, 11(3), 259-278. Available from: http://www.jstor.org/stable/ 25070790 [Retrieved 18th August, 2019].

[75] Powell, K. C., \&Kalina, C. J. (2009). Cognitive and social constructivism: Developing tools for an effective classroom. Education, 130 (2), 241-250.

[76] Prawat, R. S. \& Floden, R. E. (1994). Philosophical perspectives on constructivist views of learning. Educational Psychology, 29 (1), 37-48.

[77] Rapcsak S. Z., Henry M. L., Teague S. L., Carnahan S. D., Beeson P. M. (2007). Do dual-route models accurately predict reading and spelling performance in individuals with acquired alexia and agraphia? Neuropsychologia 45 2519-2524. 10.1016/j.neuropsychologia.2007.03.019

[78] Richard, A. (2013). Theory building in applied disciplines. San Francisco, CA: Berrett-Koehler Publishers.

[79] Riegler, A. (2004). What is radical constructivism and who are its proponents? Available at: https://www.univie.ac.at/constructivism/about.html [Retrieved $18^{\text {th }}$ August, 2019].

[80] Rogers, A.,\& Street, B. (2012). Adult literacy and development: Stories from the field. England and Wales: National Institute of Adult Continuing Education.

[81] Reese, W.J. (2013). In search of American progressives and teachers. History of Education: Journal of History of Education Society, 42(3), 320-334.

[82] Seligman, M. (1971). Phobias and preparedness. Behaviour Therapy, 2 (3), 307-320. https://doi.org/10. 1016/S0005-7894(71)80064-3. 
[83] Serpell, R. (1978). Some developments in Zambia since 1971. In S. I. Ohannessian \& M.E. Kashoki (Eds.), Language in Zambia (pp. 424-447). London, UK: International African Institute.

[84] Seymour, P. H. K., Aro, M., \& Erskine, H. J. M. (2003). Foundation literacy acquisition in European orthographies. British Journal of Psychology, 94, 143-174.

[85] Share, D. L. (1995). Phonological recoding and self-teaching: Sine qua non of reading acquisition. Cognition, 55, 151-218. DOI: 10.016/0010-0277(94)00645-2

[86] Share, D. L. (2008). On the Anglocentricities of current reading research and practice: The perils of overreliance on an "Outlier" orthography. Psychological Bulletin, 134, 584-615. DOI: 10.1037/00332909.134.4.584.

[87] Shroff, F. (2011). We are all one: Holistic thought-forms within indigenous societies indigeneity and holism. Counterpoints: Indigenous Philosophies and Critical Education: A READER, 379, 53-67.

[88] Snowling, M. J. \& Hulme, C. (Eds.) (2005). The science of reading: A handbook. Oxford, UK: Blackwell Publishing.

[89] Spencer, H. (1898). The principles of biology. New York, NY: D. Appleton \& Co.

[90] Stewart, D., \& Klein, S. (2016). The use of theory in research. International Journal of Clinical Pharmacy, 38 (3), 615-619.

[91] Taylor, G.R. \& MacKenney, L. (2008). Improving human learning in the classroom: Theories and Teaching Practices. Landam, MD: R \& L Education.

[92] Von-Glasersfeld, E. (1974). An introduction to radical constructivism. In P. Watzlawick (Ed.). The invented reality (pp. 17-40). New York, NY: Norton.

[93] Vygotsky, L.S. (1978). Mind in society: The development of higher mental processes. Cambridge, MA: Harvard University Press.

[94] Wood, D.J., Bruner, J.S. \& Ross, G. (1976). The role of tutoring in problem solving. Journal of Clinical Psychiatry, 17, 89-100.

[95] Yilmaz, K. (2008). Constructivism: Its theoretical underpinnings, variations, and implications for classroom instruction. Educational Horizons, 86(3), 161-172. Available from http://www.jstor.org/stable/ 42923724 [Retrieved 23rd August, 2019].

[96] Ziegler, J., \& Goswami, U. (2005). Reading acquisition, developmental dyslexia, and skilled reading across languages: a psycholinguistic grain size theory. Psychological Bulletin 131(1): 3-29, Doi: https:// doi.org/ 10.1037/0033-2909.131.1.3

\section{AUTHORS' BIOGRAPHY}

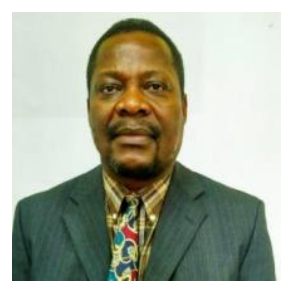

BentryNkhata $(P h D)$ is a Senior Lecturer of Mathematics Education at the University of Zambia and currently serving as Dean of the School of Education. $\mathrm{He}$ has more than a decade experience in teaching mathematics at secondary school and more than two decades as lecturer in the university. His research interest has been in teacher-knowledge and classroom practices. More recently, he has taken greater interest in lower primary school children's number sense.

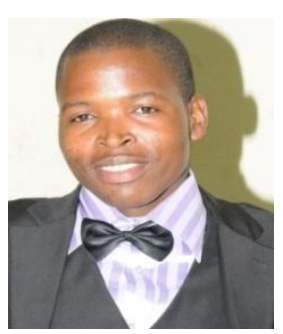

Sitwe Benson Mkandawire is a lecturer in the Department of Language and Social Sciences Education of the School of Education of the University of Zambia. He holds bachelors (BAED) and masters (MEDLL) degrees in Linguistics and African Languages with English, and, Literacy and Language, respectively. He continued with related fields and currently, he is pursuing doctoral studies in Literacy, Language and Applied Linguistics. His research interests and publications are on issues related to Research, Literacy, Language, Applied Linguistics, and Culture. He has published some articles, books and book chapters and some of these can be accessed on the following link https://scholar.google.com/citations? user=rXQm6H8AAAAJ \&hl=en\&oi=ao.

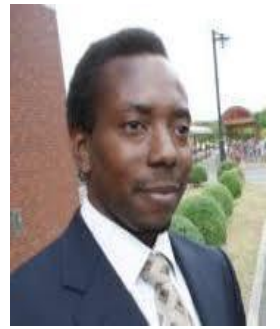

Kabunga Nachiyunde $(P h D)$ is a specialist in chemistry education. He is current lecturing at the University of Zambia, School of Education, Department of Mathematics and Science Education. His main interests include the development of teaching and learning materials that meet the needs of the $21^{\text {st }}$ century learners. These materials include Information and Communication Technology based tools and those that are derived from locally available products and have the potential to induce authentic and meaningful learning. His work focuses on combining theory 
and practice in the most novel way possible.

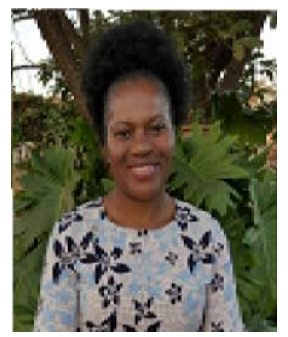

Patricia PhiriNalube $(P h D)$ is a mathematics education lecturer at the University of Zambia, School of Education, in the Mathematics and Science Education Department. She holds a Doctor of Philosophy $(\mathrm{PhD})$ in mathematics education and a Master of Science (MSc) in mathematics education both from University of the Witwatersrand, Johannesburg, South Africa. She also holds a Bachelor of Science with Education (BScEd) in mathematics education from the University of Zambia; and a Diploma in Education (Dip.Ed, mathematics) from Copperbelt Secondary Teachers' College in Zambia. Her research interests include issues pertaining to the teaching and learning of mathematics at both teacher education and school levels; female participation in mathematics; and mathematical knowledge for teaching. For one of her recent publications in the International Journal of Education (IJE), see: http://www.iaeme.com/IJE/issues.asp?JType= JE\& VType $=6 \&$ IType $=1$.

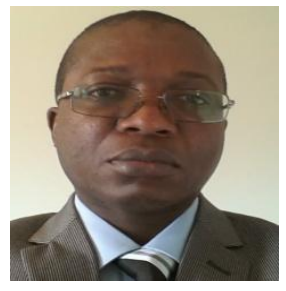

BesternKaani, $(P h D)$ is a lecturer of Educational Psychology and Special Education in the Department of Educational Psychology, Sociology, and Special Education at the University of Zambia. He holds a $\mathrm{PhD}$ in Curriculum and Instruction (Language Arts and Reading) from Texas A\&M University at College Station in Texas, USA. Both his Bachelor of Arts and Master of Education are in Special Education, which he obtained from the University of Zambia. His research interests converge around the development of literacy skills, particularly reading, among bilinguals in poorly-resourced environments focusing on the influences of orthographic transparency and variations in trajectories of cognitive development resulting from cultural differences.

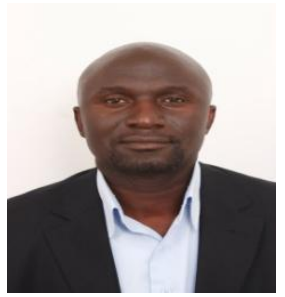

Innocent MutaleMulenga $(P h D)$ is a Curriculum and Teacher Education Scholar and Researcher at the University of Zambia in the School of Education. Dr. Mulenga has been researching, publishing, doing consultancy and teaching on issues in Curriculum Development, Implementation and Evaluation, Educational Assessment, Teacher Education, Pedagogy, Teaching and Learning in Higher Education and Vocational Education. He has also supervised and examined several masters and doctoral research projects both locally and internationally.

ORCID iD: https://orcid.org/0000-0002-2636-3630

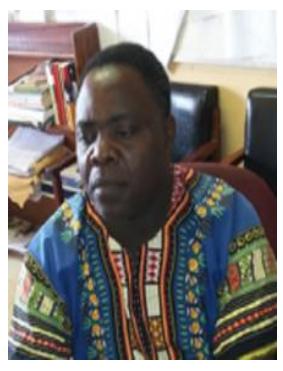

ChidongoPhiri $(P h D)$ is a lecturer of Social Sciences Education at the University of Zambia. He holds a Doctoral of philosophy $(\mathrm{PhD})$ in Sociology specialized in Governance from University of the Western Cape-South Africa. Additionally, he holds two masters of Arts degrees from Ireland and India, all in Sociology, specializing in economic development, globalization and trade unionism. His undergraduate studies were in Sociology and Development studies. He also read for a diploma in Management studies, a certificate in accounting and administration at National institute of public administration (NIPA). ChidongoPhiri has published in the following topics: Racketeering, Governance and Corruption. His research interests are in topics such as: Governance, Social theory, Gender and Sexuality, Urban poverty, Globalization, Education and Religion. He is currently reading for another doctoral of philosophy degree $(\mathrm{PhD})$ in Gender and Women's studies at University of the Free State-South Africa, in collaboration with the University of Bonn in Germany under the DAAD fellowship.

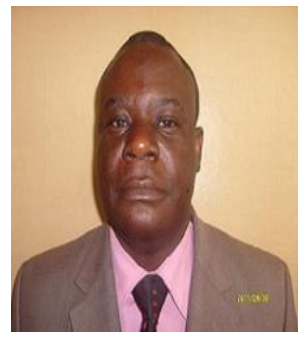

Bernard Chileshe $(P h D)$ is a lecturer in Geography and Environmental Education at the University of Zambia. He holds a Bachelor of Arts with Education, Masters (MSc) in Geography and PhD in Environmental Education. His main research interest is in sustainable resource management, including green development. His current research projects focus on environmentally significant human behavior and how indigenous knowledge systems can be used in waste and resource management in Zambia. 


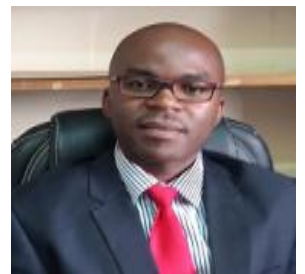

Noah KennySichula $(P h D)$ is a lecturer of Adult Education at the University of Zambia. He holds a PhD in Adult, Community Education and Training from the University of Pretoria in South Africa. His research interests include Adult learning, literacy education, extension education, social justice education, pedagogy, community education and development. He has published articles and book chapters in these areas and some of the publications can be accessed at

https://scholar.google.co.za/scholar?hl=en\&as_sdt=0\%2C5\&q=Noah+K+Sichula\&oq=Noa

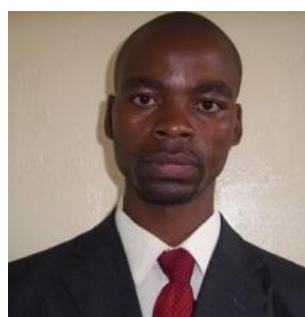

some years.

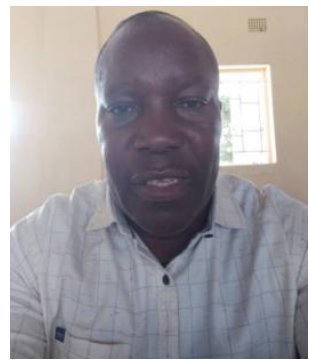

Patrick Sikayomya is a lecturer in the Department of Language and Social Sciences Education of the School of Education of the University of Zambia. He is currently serving as Assistant Dean in the School of Education. He holds Bachelor of Arts with Education degree and Master of Arts degree in History and is pursuing doctoral studies in history education at the University of Zambia. His area of research interest are in social sciences, and pedagogical issues. He is a teacher educator and has served the ministry of education for

Jonathan C. Munachaka is a Lecturer of Educational Psychology in the Department of Educational Psychology, Sociology and Special Education of the University of Zambia. He has been teaching Educational Psychology since 2007 to date. 12 years now. He is currently a PhD student in Psychology at the University of Jyvaskyla, Finland. He holds a Masters of Education in Educational Psychology and a Bachelors of Arts degree in Psychology. In addition to teaching, Jonathan has conducted extensive research and published journal articles in areas of early reading in international journals. His areas of research interest are reading, reading disability and associated interventions.

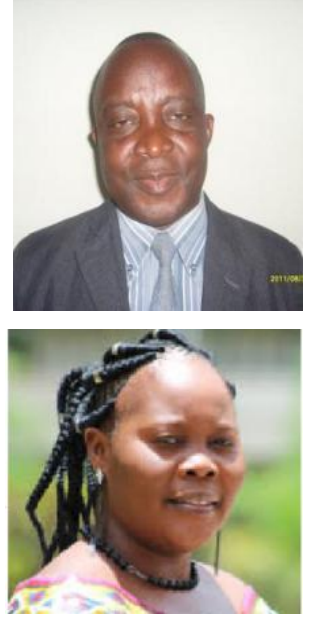

Dennis Banda is a lecturer in the Department of Language and Social Sciences Education of the School of Education of the University of Zambia. He is currently serving as Assistant Director of the Directorate of Research and Graduate Studies (DRGS) of the University of Zambia. Dennis has taught for over fifteen years at a secondary school and a decade at college and university. He is more interested in indigenous knowledge systems, language teaching and research. He has also made several publications in the same fields.

FelesiaMulauzi is a Lecturer at the University of Zambia in the Department of Library and Information Studies. She holds a Master of Science degree in Information Management. Prior to joining the Department of Library and Information Studies in 2009, Felesia served as Senior Archivist and Assistant Director at National Archives of Zambia. She has more than 13 years of professional practice. Her broad research interests include Library and Information Science (LIS) education; information needs and information seeking behaviours of individuals; Information and Communication Technologies (ICTs); records and archives management; knowledge management and information literacy.

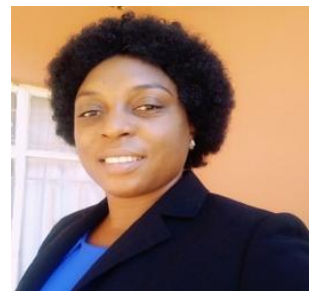

Janet Serenje-Chipindi is a lecturer in Sociology of Education at the University of Zambia. She holds a Master of Education in Sociology of Education and Bachelor of Education in Special Education from the University of Zambia. Her research examines teacher education, inclusive education and literacy skills in the early year's settings.

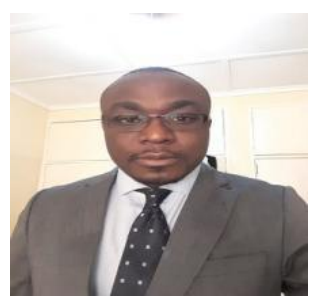

Ferdinand MwakaChipindi $(P h D)$ is Lecturer at the University of Zambia. He has taught in the School of Education for the past 12 years. He currently heads the department of Educational Administration and Policy Studies (EAPS). Dr Chipindi holds a PhD in Comparative and International Development Education, from the University of Minnesota, USA. His research interests occur at the intersection of culture, identity and education. His $\mathrm{PhD}$ dissertation 
analysed the negotiation of professional identity among University of Zambia lecturers at different epochs in the history of the institution. He is currently working on a project on the incorporating indigenous knowledge systems into sustainable development efforts.

Citation: Bentry Nkhata, et.al. "Exploring Selected Theories Applicable to Educational Disciplines and Social Sciences Research". International Journal of Humanities Social Sciences and Education (IJHSSE), vol. 6, no.12, 2019, pp. 97-116. doi: http://dx. doi.org/10.20431/2349-0381.0612008.

Copyright: () 2019 Authors. This is an open-access article distributed under the terms of the Creative Commons Attribution License, which permits unrestricted use, distribution, and reproduction in any medium, provided the original author and source are credited. 